\title{
Embedding Repetition (Takrir) Technique in Developing Al-Quran Memorizing Mobile Application for Autism Children
}

\author{
Norhalina Senan ${ }^{1}$, Wan Azizah Wan Ab Aziz, Muhammad Fakri Othman, Suriawati \\ Suparjoh \\ Department of Multimedia, Faculty of Computer Science and Information Technology, Universiti \\ Tun Hussein Onn Malaysia, Parit Raja, 86400, Batu Pahat, Johor, Malaysia
}

\begin{abstract}
Nowadays, there are various types of learning materials used in the process of teaching and learning of Al-Quran including the use of mobile application. However, the features of mobile application that are appropriate for the process of memorizing the Al-Quran, especially for the needs of children with autism is still limited. Thus, this paper proposes an interactive Al-Quran mobile application namely $i \mathrm{Hafaz}$ to facilitate autism children recite and memorizing Al-Quran. A takrir (repetition) technique in Islamic learning approach is embedded in this mobile application in order to assist autism children memorizing the Al-Quran easily. This mobile application consists of two main modules which are Hafaz (Memorize) and Latihan (Exercise). Result from the user testing shows that $72.4 \%$ of respondents agree that the takrir technique embedded in the mobile application able to improve the usability of the mobile application in helping the autism children to recite and memorize the Al-Quran easily.
\end{abstract}

\section{Introduction}

Al-Quran is the religious text that became as the main guidance in Muslim's daily life. Various efforts have been made to uphold the Al-Quran including producing more young generation who can recite and memorize Al-Quran in proper way, including children with autism. However, most of the children with autism are associated with learning difficulties [1] which cause autism Muslim children face a problem in learning Al-Quran as well. Basically, the autism children can be divided into two categories which are LFA (LowFunctioning Autism) and HFA (High-Functioning Autism) [2]. Based on their learning ability, children with LFA present with limited language and severe cognitive impairment, while children with HFA have better language development and cognitive ability.

With the difference learning disabilities, autism children require special techniques and methods that correspond to their cognitive level especially in learning Al-Quran. In Islamic

${ }^{1}$ Corresponding author: halina@uthm.edu.my 
pedagogical study, there are a few methods that can be used to facilitate Muslim to learn Al-Quran such as al-Baghdadi and Iqra which focusing on reciting Al-Quran, Jibril method to memorize Al-Quran and color technique in Mushaf Al-Quran to highlight Tajweed rules [3]. In addition, with the rapid development of IT, contemporary methods on learning AlQuran were introduced. The invention of Al-Quran apps or online version encourages Muslim to learn Al-Quran by self-learning approach. However, these methods applicable to all people regardless of their special needs especially people with learning disabilities.

Therefore, in this paper, interactive Al-Quran mobile application known as iHafaz is proposed in order to fulfill the special needs of children with autism in reciting and memorizing the Al-Quran. The target user is Muslim autism children under HFA category who had basic knowledge of Al-Quran and also minimum ability to read, write, speak (pronounce) and high intelligence level to memorize Al-Quran. For that, an Islamic learning approach called takrir (repetition) technique is embedded in this mobile application as the main feature to assist autism children reciting and memorizing the AlQuran easily. In order to increase the usability of this mobile application, visual and auditory elements such as presenting Al-Quran verses with Uthmani scripts, background color selection mechanism based on user preference, audio recitation for the autism children to imitate the right Al-Quran pronunciation, simple interface design and iconic button design are also provided.

The rest of this paper is organized as follows: Section 2 presents briefly on the related works of this study. Section 3 describes the details of the development process. A proposed mobile application iHafaz is presented in Section 4 followed by the discussion and conclusion in Section 5.

\section{Related Work}

In this section, the discussion on Al-Quran Memorization Technique, the utilization of Information Technology in learning Al-Quran for autism children and the characteristic of high-functioning autism (HFA) are presented.

\subsection{Al-Quran Memorization Technique}

Memorizing Al-Quran is the process of committing Al-Quran verses to memory. Al-Quran contains all knowledge in this world including sciences, history, medical facts, provisions, laws and many more [4]. Abduldaem [4] claims that people who memorizing Al-Quran is the memorizer of the largest encyclopedia. With that awareness, many Muslim parents nowadays send their children to Islamic school for learning and memorizing Al-Quran.

There are several techniques for memorizing Al-Quran. Based on the study in [5], there are four phases of memorizing Al-Quran implemented at Madrasah Tahfiz Al-quran, Terengganu, Malaysia which are Sabak, Para Sabak, Ammokhtar, Halaqah Dauri. In Sabak phase, they are required to memorize verse by verse based on their ability up to the point determined by the teacher. After the student able to memorize the specific verse of AlQuran, they will go for second phase which is Para Sabak. Para Sabak is weekly memorization process in pair. The pair must be at similar level for compatibility purposes. After that, in phase Ammokhtar, the student have to memorize the Al-Quran more than one juzu' in the back of recent verses. In this phase, the order and actual arrangement of the AlQuran in their reading is emphasized. Thus, canning stimulus is implemented if they forget or make mistake in their reading. Finally, after the students accomplished memorizing the whole Al-Quran, they will enter the last phase which is Halaqah Dauri. In this phase, they need to repeat the memorizing process in exact order and the performance is monitored by 
their teacher. The process will be repeated several times until they master their reading well.

Study in [6] reviews two main techniques in memorizing the Al-Quran applied at Islamic school in Indonesia which are tahfidz and takrir techniques. In tahfidz technique, face-to-face approach between student and teacher is applied during memorizing process. The teacher will check the correctness of the Al-Quran reading from the basic skill of Qiro'ti, memorizing Juz 'Amma, Bin Nadzor Juz 1 till musyafahah. While, in takrir technique, the student need to repeat the memorization process whether by musyafahah (in pair) method, by group method, orestafet (spinning) method within a group and seaman method. Takrir technique is also conducted in front of the teacher.

Another research on the Al-Quran memorization techniques was conducted in [7] where the effectiveness of the techniques applied in several tahfiz schools in Malaysia is compared. The finding shows that three techniques which are tasmiq (reciting the new memorization of Al-Quran verse), normal memorization and verse writing book are the most effective memorization techniques used among the tahfiz students. However, the most preference technique used by the teacher is the takrir technique. Therefore, it is suggested that the most preferred techniques used by both teachers and students need to be combined in order to increase the effectiveness of memorizing the Al-Quran. This is due that takrir technique is still important in the process of memorizing the Al-Quran among tahfiz student to ensure they can improve their memorization consistently.

\subsection{Utilization of Information Technology (IT) in Learning AI-Quran}

With the advancement of Information Technology (IT), many online and mobile applications regarding Al-Quran have been developed to facilitate Muslims on learning AlQuran [8][9][10]. In their study, the current technology in expert system, human-computer interface (HCI) and persuasive multimedia were applied in enhancing the efficiency of AlQuran application in order to fulfill the needs of different target user especially disable people. Instead of the technology requirement, the right way of reciting the Al-Quran is very crucial in developing the Al-Quran application in order to preserve the originality and purity of the Al-Quran. For that, in [11], the important features to be applied in Al-Quran application are highlighted including word-by-word learning system to allow the user to learn the pronunciation of Al-Quran word from the basic level, contain transliteration to pronounce the words correctly, contain audio recitation and translation of the words.

Recently, several studies have been conducted in utilizing the Information Technology to help disability people especially autism children learning Al-Quran [12][13][14][15]. In [12], a research on the literature of the mobile application for disability student in Malaysia environment from Islamic perspective has been conducted. Based on their finding, it shows that the use of IT facilities in Malaysian education is still at early stage. Thus, they belief that all parties including government authority, school and developers must cooperated and committed in the implementation of IT facilities especially the needs of Islamic teaching and learning materials for disability children especially in Malaysia. For that some effort has been done in enhancing Al-Quran learning capabilities among autism children by using IT. Kamaruzaman and Jomhari [13] proposed digital game-based learning integrated with five LACIP skills (listening, arranging, constructing, imitation and pronunciation) to assist LFA autism children learning Al-Quran. Then, in [14][15] they expand their research in assisting autism children learning Al-Quran by developing serious games based on the LACIP skills and ABAHATA Al-Jabari Al-Quran. Their finding shows that the learning interest on learning Al-Quran is increased after using the serious game. 


\subsection{High-Functioning Autism (HFA)}

An autism spectrum disorder is a brain developmental disability that affects the social skill, communication skill, social imagination skill, sensory issues and routines [16]. In addition, people with autism also have restricted, repetitive and stereotypes patterns of social behavior. With these limitations, most of the autism children experience with learning disabilities. The cognitive abilities of each autism children are different and basically can be categorized into two types which are Low Functioning Autism (LFA) and High Functioning Autism (HFA).

As compared to LFA, children with HFA have developed language and cognitive abilities. Most of HFA children have a high degree of intelligence and able to engage well in many aspects of their daily activities almost similar to normal children [17]. In learning perspective, children with HFA have basic skill to read, write and speak. However, with behavior difficulties, the way they think and learn are different from normal children. They often having problems in interacting and communicating with teachers and friends appropriately, understand the instruction and struggling in giving their attention to teaching and learning activities due to the difficulties in interpreting and understanding gestures, facial expressions or tone of voice. Therefore, they need a special treatment and approach in learning activities in order to improve their learning performance including the use of visual aids such as laminated photos or illustrations and computer software which able to show both text and image simultaneously.

\section{User Requirement Analysis}

In this study, the user requirements are analyzed based on the following activities:

a) Interview with Subject Matter Expert. An interview with Subject Matter Expert which are the teachers and Project Leader of Faqeh, Dr Nazean Jomhari was conducted at Yayasan Pendidikan Al-Quran specifically for children with special needs. The purpose of this interview session is to understand the education background of autism children including the existing teaching and learning methods used to learn and memorize Al-Quran, methods on giving appropriate instruction and guidelines on designing Al-Quran memorization mobile application that can fulfill the needs of autism children.

b) Observation on target user. The main objective of this activity is to understand the behavior and learning style of autism children especially on memorizing AlQuran. This is important to ensure the mobile application developed for them able to help them in learning and memorizing Al-Quran.

c) Review on the existing mobile applications. A review on the existing mobile applications available at Google Play was performed in order to identify the appropriate features that can be applied in the proposed mobile application.

From the activities, the following user requirements are identified and used as the guideline in developing the proposed mobile application, iHafaz:

a) Autism Children Learning Style. Each of the autism children at Yayasan Pendidikan Al-Quran has their own learning style. Some of them are auditory learner and some are visual learner. In this institution, both visual and auditory methods were applied in learning and memorizing Al-Quran. Currently, cardboard was used as learning material to display the Al-Quran verses. Simultaneously, the teachers will recite the Al-Quran verses and followed by the students. These methods are used to support both visual and auditory learners. 
b) Al-Quran Memorization Technique. Takrir (repetition) was applied in this institution for learning and memorizing Al-Quran. In average, they need to repeat 60 times of each verse in order for them to memorize it.

c) Content of Mobile application. 10 chapters from Juz Amma which are Al-Fatihah, Al-Nas, Al-Falaq, Al-Ikhlas, Al-Masad, Al-Nasr, Al-Kafirun, Al-Khautar, AlMaun and An-Quraish are selected. These chapters are short chapter which not more than 7 verses. Simple activities should be provided in order to attract autism children engage with this mobile application. Malay language is utilized (except for the recitation of Al-Quran verses) for better understanding since this language is used in their daily communication.

d) Multimedia elements. Multimedia elements used in this mobile application are simple text from Comic Sans MS family for instruction and button, Al-Quran text with Uthmani scripts, audio with .wav file format for reciting the Al-Quran verses, and graphics with .png file format for button and background design.

e) Interface Design. The interface design for autism children should be simple, clear and easy to learn. It is also suggested to apply adaptable user interface where the autism children are allowed to change background colour or size of text based on their own preference.

\section{4 iHafaz Prototype}

The proposed application namely iHafaz is developed on mobile platform using Adobe Flash Professional CS6 with Actionscript 3.0. A simple interface design concept with less graphic and animation is applied in this prototype. The purpose is to attract the attention of autism children to focus on important information and not be distracted by non-essential content. In addition, to improve the usability of this mobile application, all the instructions and contents are delivered using audio and displayed in a large size and well-organized. In general, this prototype consists of 3 main modules which are Hafaz (Memorize), Latihan (Exercise) and Audit as shown in Figure 1.

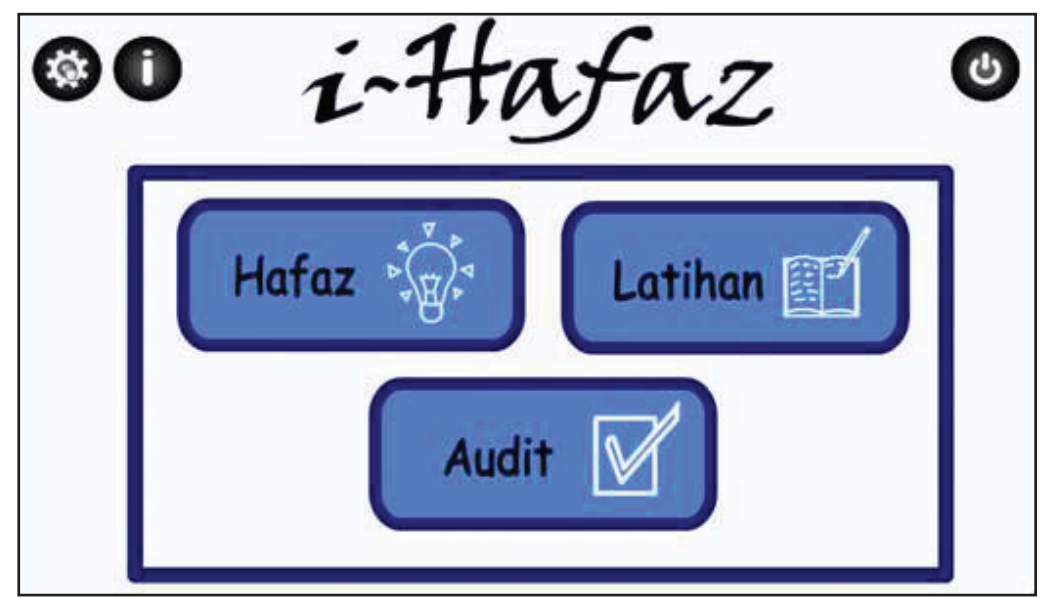

Fig. 1. Main interface.

In Hafaz module, a list of 10 selected chapters in Juz Amma as shown in Figure 2 is provided. Each chapter button is assigned a number from 1 to 10 to help autism children 
easily recognize the sequence of the chapter and select the desired chapter.Al-Quran text with Uthmani scripts is utilized since autism children were familiar with this text which used in printed version.

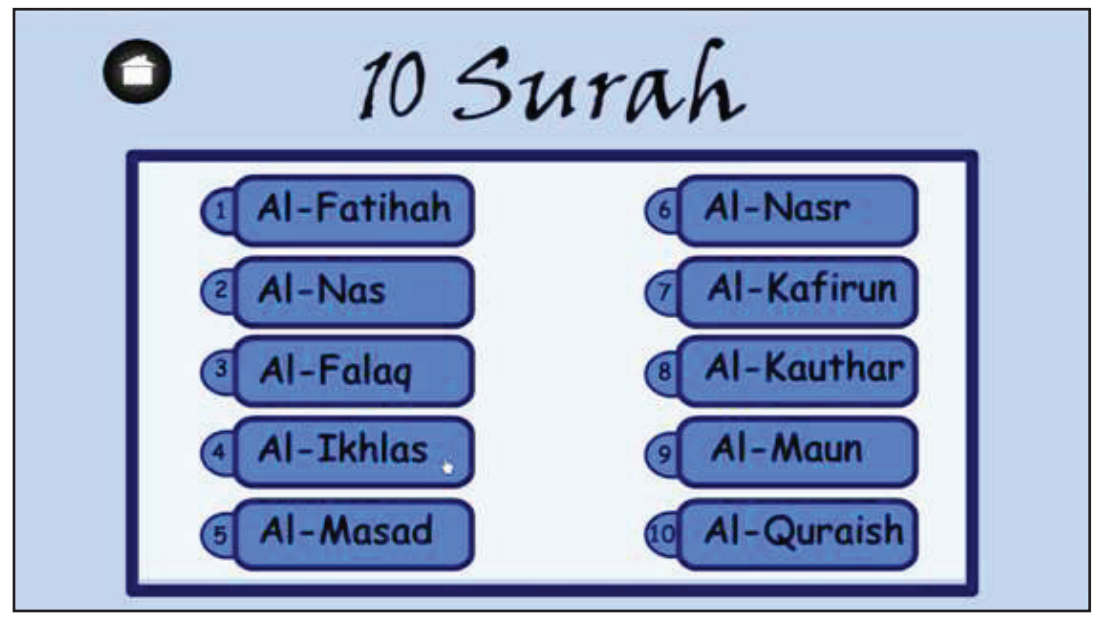

Fig. 2. A list of 10 chapters from Juz Amma.

The selected chapter is displayed as shown in Figure 3. The verses of the chapter are segmented and displayed line by line to make it easier for autism children to recite and memorize it.Then user can press on each verse and the selected verse will be displayed in bigger size (see Figure 4). In this module, a takrir technique is embedded to facilitate autism children to recite and memorize the chapter. It is done by providing the audio of verse recitation and repetition button at the bottom of each verse. The user needs to follow the recitation and memorize the verse. To help the autism children give their attention and focus on the recitation, the pointer on the highlighted verse is provided simultaneously with the audio. After that, the repetition button need to be pressed and the number of repetition will be displayed at the upper corner right of the interface as the indicator to the user. The maximum number of repetition in this mobile application is 60 as determined by the Subject Matter Expert.

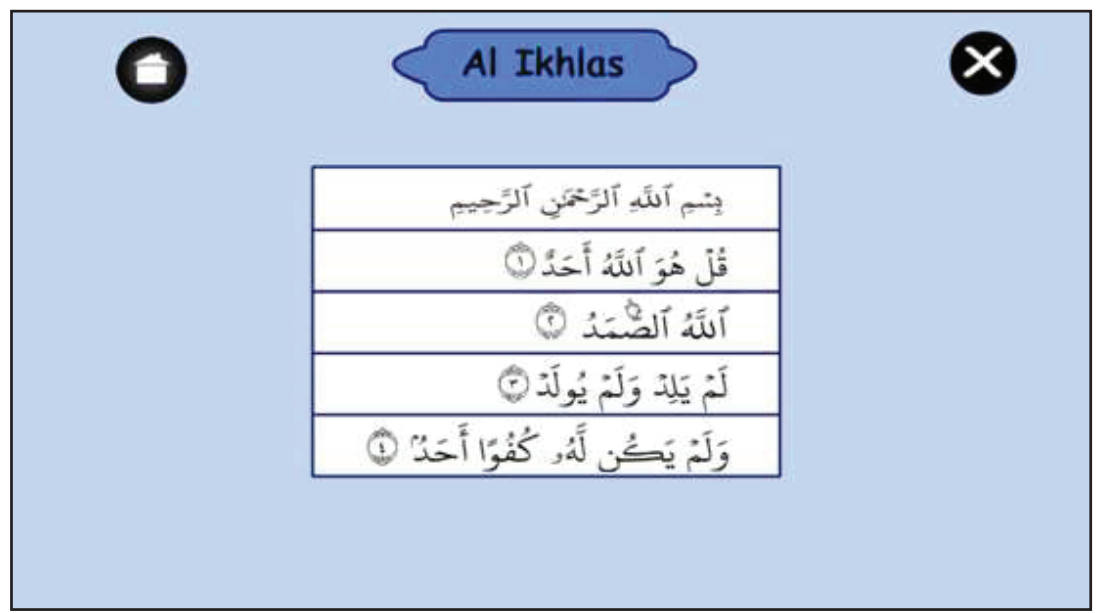


Fig. 3. Surah Al-Ikhlas.

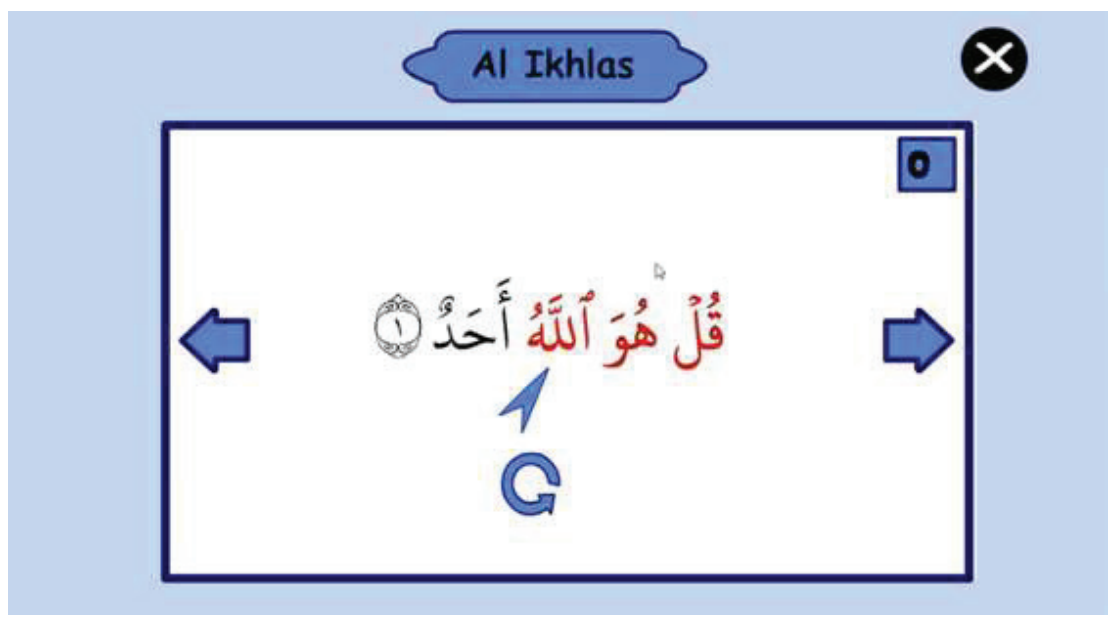

Fig. 4. Embedding takrir technique for assisting autism children memorizing Al-Quran.

In Exercise module, an exercise using serious game with 'drag and drop' approach is provided. The exercise comprises of 3 levels which are easy, medium and difficult. In easy and medium level presented in Figure 5 and Figure 6, the cue of the verses is provided to facilitate autism children do the exercise with fun approach. This is important to avoid them feel frustrated at early stage and eventually refuse to use this mobile application if they feel that the exercise are too difficult to be solved. The ability of the user to memorize the verses of each chapter can be tested in Difficult Level where the user needs to rearrange the verses by the correct sequence without any cue (See Figure 7). In each level, the correct answer will be marked and the praise audio such as "Congratulation" is produced as the rewards to motivate the autism children. The last main module is Audit module shown in Figure 8. In this module the user can tick on the chapter that has been memorized. At the same time, the teachers also can monitor the progress of each student through this module.

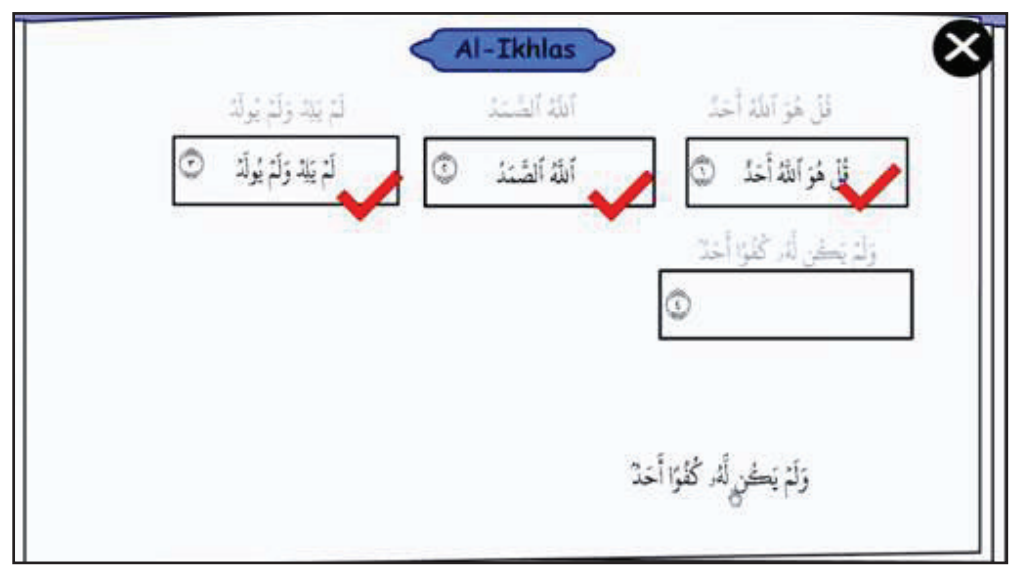

Fig. 5. Easy level of memorization exercise. 


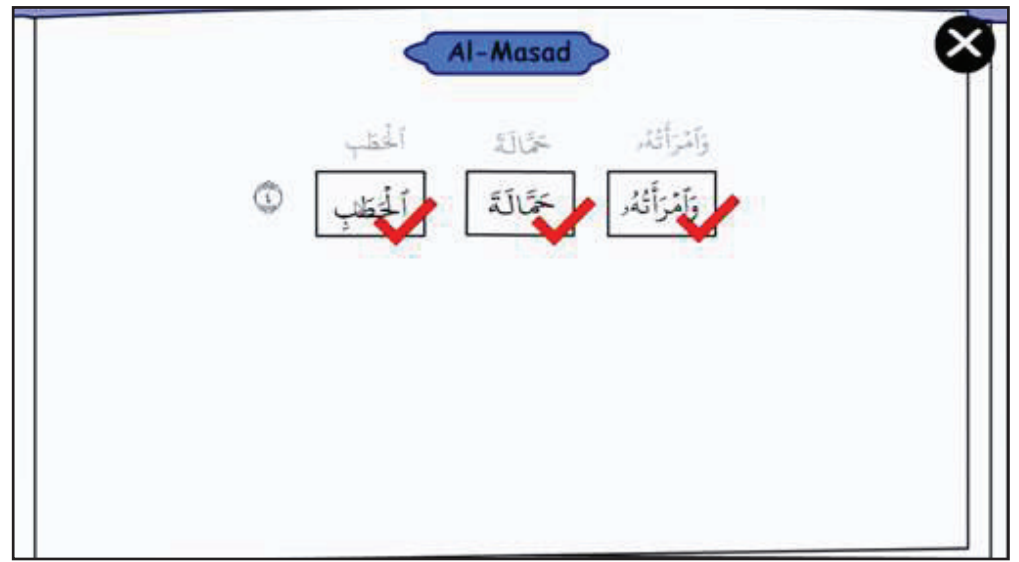

Fig. 6. Medium level of memorization exercise.

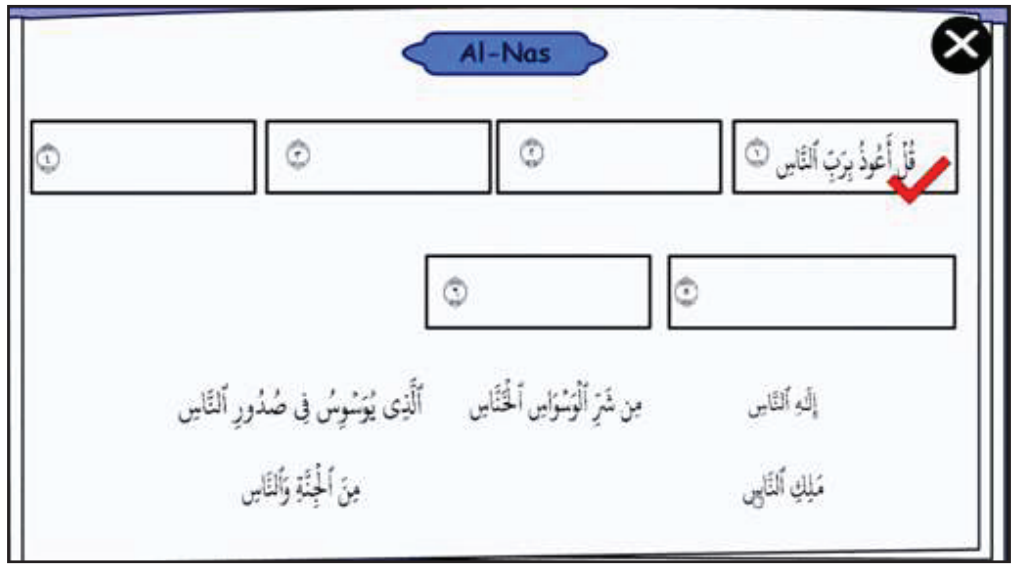

Fig. 7. Difficult level of memorization exercise.

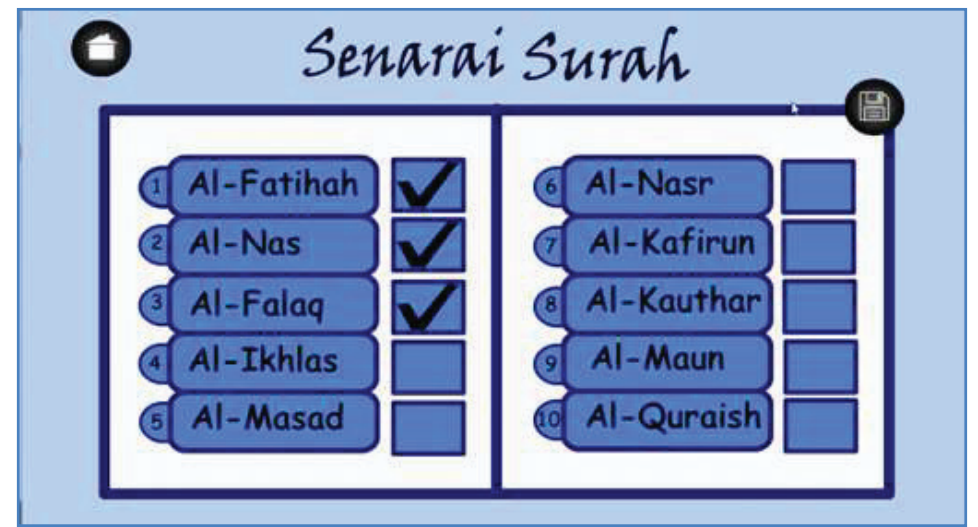

Fig. 8. Audit module. 
Instead of these 3 main modules, other modules provided in this prototype are Setting and Info modules. In order to handle individual preference, user is allowed to change the colour of the background in this module. There are 5 different soft colours which are white, purple, green, blue and grey provided in this prototype. The user only need to click on the preferred colour and then the background colour of the whole prototype will be changed accordingly. The colour is selected based on the observation on the target user and the existing applications.

\section{Result and Discussion}

In order to identify the advantages and disadvantages of the prototype, user testing is conducted for two groups of target user which are autism children and teachers as Subject Matter Expert. The total number of respondent is 13 where the number of teachers and autism children are 6 and 7 respectively.

The teacher's acceptance rate is measured in term of their satisfaction level on the use of takrir technique, adaptable user interface approach, the selected colours, the size of text and the quality of the audio used. The result presented in Figure 9 shows that $67 \%$ of the teachers agree that use of takrir technique and the recitation of the Al-Quran in iHafaz able to facilitate autism children in learning and memorizing the Al-Quran. However, $37 \%$ of the teachers feel that the audio of the recitation is too fast but agree with the use of takrir technique in this prototype. While only $50 \%$ of users agree that the size of the text used in this prototype is suitable to be read by autism children and the rest feel that the size of the text used is quite small and difficult to read by autism children. It is suggested to use larger text size for better reading performance. Surprisingly, more than $80 \%$ of the teachers agree with the utilization of adaptable user interface approach, the selected colours and the quality of the audio used in this prototype.



Fig. 9. Teacher's acceptance rate.

Figure 10 shows that more than $85 \%$ of the autism children agree on the use of the takrir technique and recitation audio in assisting them memorizing the Al-Quran. They are 
also agreeing that the prototype is attractive, the instruction is clear and the exercise provided is fun and easy to use. However, most of them feel that the text size used is too small and hard to be read. In average $84.5 \%$ of both teachers and autism children agree that the takrir technique embedded in $i$ afaz capable to assist them in learning and memorizing the Al-Quran. Whereas, overall $72.4 \%$ of both respondents agree that the interface design for $i H a f a z$ mobile application is easy to use, easy to learn and able to provide an enjoyable experience.



Fig. 10. Autism children's acceptance rate.

\section{Conclusion and Future Work}

In conclusion, most of the autism children involved with learning disability including in learning and memorizing Al-Quran. Thus, appropriate methods which able to facilitate them in learning and memorizing Al-Quran are required. In this study, the takrir technique embedded in iHafaz prototype able to assist autism children in reciting and memorizing the Al-Quran easily. The simple interface design with adaptable user interface approach; high quality audio for recitation and instruction; well-structured content and fun learning approach are important features to be considered in attracting autism children in reciting and memorizing Al-Quran using new technology. Results from user testing show that both teachers and autism children satisfied with the performance of the iHafaz prototype. However, some improvements on interface design such as identifying the appropriate size of text and enhancing the features of adaptable user interface where the autism children has ability to change the size of text based on their own preference are required. This is important in order to increase user's satisfaction level.

\section{References}

1. R. Jordan, Autism with Severe Learning Difficulties, Souvenir Press (2013)

2. K. A. Feather, Low Functioning to High Functioning Autism: A Prescriptive Model for Counselors Working with Children across the Spectrum, the 56th Annual European Branch of the American Counseling Association Conference, Naples, Italy (2015) 
3. S. P. B. Mohamad, Z. B. M. Yusoff, D. S. B. H. Adli, Pengajaran Dan Pembelajaran Al-Quran Bagi Golongan Kelainan Upaya Mental: Analisis Dari Sumber Tradisi Islam. Jurnal Islam dan Masyarakat Kontemporari, 8, 153-168 (2014)

4. A. Al-Kaheel, Innovative Way to Memorize the Quran. Retrieved from www.hakeel7.com/eng (2017)

5. S. Ariffin, M. Abdullah, I. Suliaman, K. Ahmad, F. Deraman, F. A. Shah, M. Y. Z. M. Yusoff, M. M. A. Razak, M. M. M. Noor, J. T. Meftah, A. K. Kasar, S. Amir, M. R. M. Nor, Effective Techniques of Memorizing the Quran: A Study at Madrasah Tahfiz, AlQuran, Terengganu, Malaysia, Middle-East Journal of Scientific Research 13 (1): 45 48 (2013)

6. Sukati, Studi Komparatif Tentang Metode Menghafal Al Qur'an. ITERASI 5(2) (2015)

7. A. H. Abdullah, A. Safar, M. I. Mustari, A. Muhammad, I. Ismail, Keberkesanan Kaedah Hafazan Di Pusat Tahfiz. Pusat Pengajian Islam Dan Pembangunan Sosial, Universiti Teknologi Malaysia (2003)

8. A. Muhammad, W. Z. Qayyum, S. Tanveer, A. Martinez-Enriquez, A. Z. Syed, Ehafiz: Intelligent system to help Muslims in recitation and memorization of Quran, Life Science Journal, 9(1), 534-541 (2012)

9. F. Razaly, N. H. Ajizan, S. Saad, M. S. Yaacob, M. M. Zain, M. Hussein, A. R. Musa, Dedicated graphical user interface system for the visually impaired users in learning Al-Quran, In Proceedings of the 9th WSEAS international conference on Applications of computer engineering, pp. 210-213, World Scientific and Engineering Academy and Society (2010)

10. A. F. Rosmani, N. A. Wahab, i-IQRA': Designing and constructing a persuasive multimedia application to learn Arabic characters. In Humanities, Science and Engineering (CHUSER), 2011 IEEE Colloquium on pp. 98-101, IEEE (2011)

11. Quran Reading, Islamic Knowledge: The Modern Ways of Leaning Quran. Retrieved March 1, 2017, from www.quranreading.com (2010)

12. N. Z. M. Zain, M. Mahmud, A. Hassan, Utilization of mobile apps among student with learning disability from Islamic perspective, In Information and Communication Technology for the Muslim World (ICT4M), 2013 5th International Conference on, pp. 1-4, IEEE (2013)

13. N. N. Kamaruzaman, N. Jomhari, N. Kamarulzaman, M. Z. M. Yusoff, Digital GameBased Learning for Low Functioning Autism Children in Learning Al-Quran, In Advances in Information Technology for the Holy Quran and Its Sciences (32519), 2013 Taibah University International Conference on, pp. 184-189, IEEE (2013)

14. N. N. Kamaruzaman, N. Jomhari, N. Kamarulzaman, M. Z. M. Yusoff, Engaging Children with Severe Autism in Learning Al-Quran through the Serious Game, Indian Journal of Science and Technology, 9(40) (2016)

15. N. N. Kamaruzaman, N. Jomhari, N. Kamarulzaman, M. Z. M. Yusoff, Digitizing Abahata Al-Jabari Method using LACIP Skill Theory to Support Learning Al-Quran for Children with Low-Functioning Autism: A Review towards Al-Quran Perspective, QURANICA, International Journal of Quranic Research, 7(1) pp. 1-16 (2015)

16. The National Autistic Society, Autism Spectrum Disorders: A Resource Pack for School Staff. Retrieved March 9, 2017 from www.autism.org.uk (2011)

17. M. L. Secor, High Functioning Autistic, Retrieved March 9, 2017 from www.autismspeaks.org (2013) 